\title{
The Utilization Effect of Video Learning Media Through Critical Thinking Skills and Student Learning Outcomes towards Tenth Grade Student in Sociology Subject at SMA 1 Banyuasin II
}

\author{
Sri Sumarni \\ Sriwijaya University, \\ Palembang, Indonesia \\ rikaferanita_tp2011@yahoo.co.id
}

\author{
Rika Feranita \\ Senior High School Number 1 Banyuasin II, \\ Banyuasin, Indonesia
}

\begin{abstract}
This research aims to find whether there is an influence of video on critical thinking skills and learning outcomes and to determine the relationship of critical thinking skills for student learning outcomes. The method used is a quasiexperimental design with nonequivalent control group design experiment. The sampling technique was cluster random sampling. The experimental class gets lesson using video media, while the control class was using power point. Data collection techniques uses are test and observation. To influence of video on critical thinking skills of the experimental group the control group and of this study using the Mann Whitney test, because the test results are not statistically significant, so we can accept the null hypothesis that there is no difference in the average skills of critical thinking experimental group and the control group. For the influence of video on learning outcomes, of the MannWhitney test, because the test results are statistically significant, so we can accept the alternative hypothesis that there are differences in average achievement (post-test)of the experimental group and the control group. Both of the test results hypothesis have a positive relationship between critical thinking skills and learning outcomes. Based on the analysis, the authors advocated on behalf of the school in order to empower complement or media equipment to smooth the process of learning, motivating teachers to enhance learning and creativity in creating fun, the results of this study can be made of materials for consideration in future research in developing and expanding the scope of learning media sociology.
\end{abstract}

Keywords-Learning Video; Critical Thinking Skills; Learning Outcomes

\section{INTRODUCTION}

The video is one of the media which can be used in social studies, for example in sociology. Although it has some disadvantages such as the difficulty in obtaining and producing, the video has advantages over the other media and very suitable for use in teaching sociology.

Sociology is taught to the tenth-grade students for two hours in a week. At the eleventh and twelfth grade, the time allocation for sociology would be 5 hours per week and the government has to put sociology into the national exam for the
Social Sciences in high school level. By learning sociology, senior high students are intended to develop students' skills towards the paradigm happened in their daily life.

The video is an alternative way to invite the students to think way more critical and get a better result in comprehending the lesson given. Based on this situation, the writer chooses to study about video as a media learning to help students think critically so they can get better outcomes for learning. This study will be implemented in public school of Senior High School of Banyuasin I, the district of Banyuasin II- the writer's workplace.

Based on observation and interviews with some students on the 10 September 2012 information was obtained, that social science has many of the concept and the theory that must be controlled. The Students tend to just memorize and interactive learning in the classroom become so monotonous because they were not directly involved in the learning process, making them be passive students. When they are given a simple test, most of them showed the lack of understanding. Besides, the situation and learning condition become uncomfortable, noisy, and some of the students seems joking around instead of listening to the teacher. The data of sociology learning outcomes which was obtained after the 2012/2013 semester test showed that the majority of students did not reach the specified standard value, which is 71 points. This indicates that the ability of students to comprehend the material given remains low.

The problems that emerged in SMA 1 Banyuasin II is students were not willing to follow subjects sociology. During the presentation, teachers tend to use the lecture method and less creative in presenting the material. Based on this, the writer needs to seek an appropriate teaching aid to improve students ability to think critically in analyzing the questions given on the subjects of sociology, by using instructional media such as video. From the problem above the writer need to do a study entitled "The Utilization Effect Of Video Learning Media Through Critical Thinking Skills And Student Learning Outcomes Towards Tenth Grade Student In Sociology Subject At SMA 1 Banyuasin II". 


\section{METHODS}

The method used in this study is quasi-experimental design with experimental non-equivalent control group design. In this design, experimental class and control class is not chosen randomly. This design can be seen in figure 1 in [1].

Where $\mathrm{O} 1$ is the value the pre-test value of the experimental class. $\mathrm{O} 2$ is the value of the post-test of experimental class. O3 is the value of pre-test control group, and $\mathrm{X}$ is a treatment namely in the form of video instructional media usage.

\begin{tabular}{|c|c|c|}
\hline $\mathbf{o}_{1}$ & $\mathbf{X}$ & $\mathbf{O}_{2}$ \\
\hline $\mathrm{O}_{3}$ & & $\mathbf{O}_{4}$ \\
\hline
\end{tabular}

Fig. 1. Design of study

The technique the sample is done by clusters random sampling. Clusters of random sampling is a method the of collecting at random ( scrambled) based on a group or class, not based on its members. The fourth group has almost the same ability so that the selection of experimental class and control done by a draw, not based on other considerations.

The experimental group uses in structional media such as video. While the group using instructional media powerpoint designated as the control group. Before the treatment, each group is given a pre-test first, then followed by dosing treatment using video media in the experimental class and powerpoint media in the control class. Furthermore, each class is then given a post-test to see the results of the treatment.

This research was conducted at SMA 1, Banyuasin II at Jalan Desa Jaya Eka Breech I, District II Banyuasin. The study is held in the second-semester academic year of 2012-2013. T he population is all the students in tenth grade of SMAN 1 Banyuasin II total 142 students. Detail samples of 71 students: 35 students experimental group and 36 students of the control group.

Data collection techniques in this study are using instruments of pre-test, post-test, observation, critical thinking skills, and critical thinking skills test. The writer uses statistic test to process the data. Validity test results for pre-test using the coefficient $(r)>0.3$, question $1=0,528$, question $3=0,343$, question $4=, 582$, question $6=0,744$, question $7=0,744$. Thus, the question test is valid. The lowest measurement results about the validity test of critical thinking skills in the coefficient of Corrected Item-Total Correlation $=0.336$ and coefficient $(r)$ is the highest $=0.793$. This shows coefficient $(r)>0.3$, then test the validity of the test of critical thinking is valid. Reliability indicates an instrument that can be used as a data collection tool, as an instrument that can be trusted and reliable will produce reliable data.

An instrument is reliable if it has a value of Cronbach's Alpha $(\alpha)>0.06$. The measurement results of reliability test is a matter of pre-test Cronbach's Alpha value which is above 0,06 . The measurement results about the reliability test of critical thinking skills. The test result reliability by Cronbach's Alpha coefficient $(r)=0.65$ and the lowest coefficient $(r)$ is the highest $=0.873$. This proves the reliability of the data processing is considered reliable because of the value of Cronbach's Alpha already above 0.60. Hypothesis test using Mann Whitney test and simple regression analysis.

\section{RESULTS AND DISCUSSION}

The study was conducted in the 2nd semester of the academic year of 2012/2013 in SMAN 1 Banyuasin II that lasted four meetings with the matter "Deviant Behavior". The author conducted an instrument test on February 11, 2013, in the class X.2 involving 34 students at the same place. The first meeting was a pre-test in the experimental class, control class on February 18, 2013, and the fourth meeting conducted posttest to see student learning outcomes on 9 of March.

The observations were made during the four meetings in the experimental class and control class, the study used data obtained at each meeting by taking the average value. This observation is assisted by three observers. A number of students on this observation for the experimental class are 35 and control class are 36. Assessment based on predefined intervals with the results of observations obtained a score, for the observation of the experimental class score is as follows: Excellent frequency criterion $3=8.6 \%$, good criteria frequency of $13=37.1 \%$, sufficient criteria frequency of $17=48.6 \%$ and fewer criteria frequency $2=5.7 \%$. In control classes of the average value of four meetings can be obtained: excellent scores criteria frequency $1=2.9 \%$, Good Frequency $5=$ $14.3 \%$, good Frequency $20=57.1 \%$, less Criteria $9=25.7 \%$. So if we compare it, that there are differences between the results of the control class and experimental class which given a treatment. This means that the use of video media based on observations affect students' critical thinking skills.

Ref. [2] states to determine whether the distribution of the data have normal distribution or not analytically by using Kolmogorov-Smirnov test for multiple samples. In this study, the number of samples> of 71 for the experimental group numbered 35 students and control groups totaling 36 students. The test results of normality and homogeneity of critical thinking skills and learning results presented in Table I below:

TABLE I. NORMALITAS DATA

\begin{tabular}{|l|l|l|l|}
\hline \multirow{2}{*}{} & \multicolumn{3}{|c|}{ Kolmogorov-Smirnov $^{\text {a }}$} \\
\cline { 2 - 4 } & Statistic & Df & the p-value \\
\hline Study Results & 0.128 & 71 & 0.006 \\
\hline Critical Thinking & 0.160 & 71 & 0.000 \\
\hline
\end{tabular}

In table I above obtained the learning outcomes for both samples significance value $\mathrm{p}$-value $=0.006<0.05$ so $\mathrm{p}$-value $<\alpha$. Thus the samples come from the population abnormal distribution. In the second critical thinking significance value $\mathrm{p}$-value $=0.000,<0.05$ to $\mathrm{p}$-value $<\alpha$. Thus the samples come from the population abnormal distribution.

Statistical test results of pre-test and post-test experimental group with a sample of 35 students is as follows: for pre-test with mean 60.91, median 60.00, variant 94845 , the standard deviation of 9739 , the highest score (maximum) is 80 , the 
lowest score ( minimum) 40, range 40 and a total score of 2132. Pre-test scores ranged from 40-80 including fewer criteria, pretty and nice. For the post-test mean 77.74, median 78.00, 27020 variants, the standard deviation of 5198, the highest score (maximum) is 90, the lowest score (minimum) 65 , range 25 and a total score of 2721 . Post-test scores ranged from 40-80 including good and very good criteria.

Statistical test results Pre-test and post-test control group with a sample of 36 students is as follows: for pre-test with mean $=62.27$, median $=63.00$, variance $=51299$, standard deviation $=7162$, the highest score $($ maxsimum $)=75$. lowest score $($ minimum $)=45$, range $=30$ and total score $=2233$. Pretest scores ranged from 40-75 including less criteria, good and very good. Post-test mean $=70.71$, median $=70.00$, variance $=$ 36387 , standard deviation $=6,032$, the highest score (maxsimum) is 85 , the lowest score (minimum) 55, range 25 and a total score of 2540. Post-test scores range between 55- 85 including less, good, and very good criteria.

The highest score of statistical test results for critical thinking skills of the experimental group with the total sample of 36 students is 88 , the lowest score (minimum) 66, mean 76.83 , median 76.50 , variance 24308 , the standard deviation is 4.930 , range 21 , and the total score 2692. Scores ranged from 66-88 including good and very good criteria.

The results of statistical tests of learning outcomes of the control group with a total sample of 36 students to critical thinking skills are as follows: the highest score (maximum) is 82, the lowest score (minimum) 58, mean 71.57, median 72.50, variant 27179 , the standard deviation of 5213, range 25 and a total score of 2580 . for the scores ranged from 58-82 including good and very good criteria.

This study used two groups, the experimental group, and the control group. In the experimental group, the intervention is given in the form of video and control groups using powerpoint media. Both groups were given an assessment in the form of pre-test and post-test. It is intended to measure or to know the difference before and after the treatment is done in one group. For a normally distributed data hypothesis test using the t-test, and for abnormally distributed data using the Mann-Whitney.

Testing the first hypothesis, the authors used the MannWhitney test to determine whether or not the difference of the two sets of data derived from independent samples. MannWhitney test is a non-parametric test that is an alternative to the t-test (parametric test) Based on table I of critical thinking, both samples of significance $\mathrm{p}$-value $=0.000,<0.05$ so that the $\mathrm{p}$ value $<\alpha$. Thus, the samples come from the population of abnormal distribution. The results are down below:

TABle II. Average Distribution of Critical Thinking FOR EXPERIMENTAL GROUP AND CONTROL GROUP

\begin{tabular}{|l|l|l|l|l|}
\hline Critical Thinking & Mean & $\begin{array}{c}\text { Standard } \\
\text { Deviation }\end{array}$ & P value & N \\
\hline
\end{tabular}

\begin{tabular}{|c|c|c|c|c|}
\hline $\begin{array}{c}\text { Experimental } \\
\text { Group }\end{array}$ & 76,83 & 4,930 & \multirow{2}{*}{0,753} & 35 \\
\cline { 1 - 3 } Control Group & 71,57 & 5,213 & & 36 \\
\hline
\end{tabular}

Based on Table II above, we can see that the mean of the experimental group 76,83 with a standard deviation of 4.930 . As for the control group, the mean value was 71,57 with a standard deviation of 5,213. From the Mann-Whitney test, the statistical results obtained $\mathrm{p}=0.753>0.05$ means alpha $5 \%$, therefore the test results are not statistically significant, so we can accept the null hypothesis that there is the no different average between critical thinking skills experimental group and control groups.

The second hypothesis was using the Mann-Whitney test. Based on Table I, for two samples of learning outcomes significance $\mathrm{p}$-value $=0.006<0.05$ so $\mathrm{p}$-value $<\alpha$. Thus, the samples come from the population of abnormal distribution. The results are in Table III as follows:

TABLE III. Distribution OF THE AVERAGE LEARNING OUTCOMES OF EXPERIMENTAL GROUP AND CONTROL GROUP

\begin{tabular}{|c|c|c|c|c|}
\hline $\begin{array}{c}\text { Learning } \\
\text { Outcomes }\end{array}$ & Mean & $\begin{array}{c}\text { Standard } \\
\text { Deviasi }\end{array}$ & P value & $\mathbf{N}$ \\
\hline $\begin{array}{c}\text { Experimental } \\
\text { Group }\end{array}$ & 77,74 & 5,198 & & 35 \\
\cline { 1 - 3 } Control group & 70,71 & 6,032 & & 36 \\
\hline
\end{tabular}

Based on Table III above, we can see that the mean of the experimental group was 77.74 with a standard deviation of 5.198 whereas for the control group, the mean value of 70.71 with a standard deviation of 6.032. From the Mann-Whitney test, the results of statistical p-value were $0.00<0.05$ significant at alpha $5 \%$ because the test results were statistically significant, so we can accept the alternative hypothesis in which there is an average difference of learning outcomes (post-test) experimental group and the control group.

Simple linear regression analysis is a linear correlation between the independent variable $(\mathrm{X})$ to the dependent variable (Y). This analysis is determining the direction of the relationship between the dependent and independent variables, whether positive or negative and to predict the value of the dependent variable when the independent variables increase or decrease. Results of regression with statistic test between critical thinking (Y1) to learning outcomes (Y2) experimental class can be seen in Table IV below:

TABLE IV. CORRELATION AND REGRESSION ANALYSIS OF CRITICAL THINKING AND LEARNING OUTCOMES

\begin{tabular}{|c|c|c|c|c|}
\hline Variable & $\mathbf{r}$ & $\mathbf{R}^{2}$ & $\begin{array}{c}\text { Regression } \\
\text { Equation }\end{array}$ & $\begin{array}{c}\mathbf{P} \\
\text { value }\end{array}$ \\
\hline $\begin{array}{c}\text { Learning } \\
\text { Outcomes } \\
\text { Test }\end{array}$ & 0,500 & 0,25 & $\begin{array}{c}41,235+0,466^{*} \\
\text { critical thinking }\end{array}$ & 0,002 \\
\hline
\end{tabular}

The results of the variable Y1 (critical thinking) with Y2 (learning outcomes) obtained 0.500 means that there is a significant correlation. According to Table IV above, it can be seen that the experimental group with a sample of 35 students, 
resulting in $\mathrm{p}$ value $>0.002$. This means that the correlation between critical thinking skills and learning outcomes showed a positive relationship. Ha accepted and Ho rejected. Which means that it is proved that critical thinking has a significant influence on learning outcomes.

Results of analysis of critical thinking skills to the learning outcomes can be seen in Table IV above which shows the correlation coefficient $(\mathrm{R})=0.500$. This means that the relationship of critical thinking skills to the learning outcomes are significant. The magnitude of the correlation numbers between 0.41 to 0.60 means that the correlation between skills, critical thinking, and learning outcomes is middling [3].

Table IV also shows the value of the coefficient of determination (R-square) of 0.500 which means the positive effect on the real learning outcomes. The coefficient of determination (R2) of 0.250 can be interpreted relationship of critical thinking skills to the learning outcomes by $25 \%$, and the remaining $75 \%$ is influenced by factors that are not investigated. Simple linear regression equation $y=a+b X$. Value $\mathrm{a}=41.235$ and $\mathrm{b}=0466$.

Based on Table IV above a simple linear regression equation $\mathrm{y}=41.235+0.46 \mathrm{X}$. This means that if there are no student learning outcomes or equal to zero, so the students' critical thinking 41.235. And if the result of learning to ride for the unit, then the critical thinking skills to rise by $4.6 \%$.

In this research, the media used in teaching and learning is video. The use of instructional media in teaching and learning can generate new interest and desire, motivation and stimulation of learning activities, and even bring psychological effects on students. The use of instructional media in teaching orientation phase will greatly help the effectiveness of the learning process and delivery of messages and content at the time so that the objectives of the learning can be achieved optimally.

Use of videos can help students to understand phenomena in everyday life (life in the real world), which impact on thinking skills. Critical thinking can help students in improving the understanding of the material being studied, students are no longer as passive learners but rather as an active part of learning.

Based on the description of critical thinking indicators, implementation of foster critical thinking skills in teaching sociology classes $\mathrm{X}$ made through the group discussions and observed by the observer. Before all students are divided into small groups of 5-6 people, then each group to discuss what they see in the video of deviant behavior. Later, representatives of each group read out the results of the discussion. In this activity, students are encouraged to actively engage in dialogue through questions and answers, submit opinions and provide feedback. Teachers help explain some of the things that have not been resolved in the discussion, and direct students to conclude the discussion.

According to the Table IV of the experimental class, the observation of the score are; criteria frequency of "very good" $3=8.6 \%$, criteria frequency of "good" $13=37.1 \%$, criteria frequency of "sufficient" $17=48.6 \%$ and criteria frequency of "less" $2=5.7 \%$, for the class control of the average value of four meetings obtained: score criteria frequency of "very good" $1=2.9 \%$, criteria frequency of "good" $5=14.3 \%$, the criteria frequency of "sufficient" $20=57.1 \%$, the criteria frequency "less" $9=25.7 \%$. There were no differences in outcomes between the treated experimental class, and control class. That is, based on observations above, the use of video media affect students' critical thinking skills.

Teaching "critical thinking" on learning using video media is an attempt to bridge the gap between the problems of teaching in schools with problems in the field (the real world). Thus, the need to take the classroom experience of teaching critical thinking that is relevant to students' daily lives. By looking at the video, students will explore and develop their ability to think critically.

Critical thinking is also growing through the test, in which students think critically to answer the questions in the test. In answering the question, the students understand how to think critically. Previously, students read about, then they try to understand the intent of the question and the subsequent. Then, the students think Which / is the right answer to that question. In that way, we learn how to think critically.

Students integrate all the information obtained from the video, given the case, as well as a number of questions to be answered and the reason for an assignment. The questions to encourage students to think critically and can be used as a source of learning.

The number of samples in this study is quite a lot of 71 students so that the test to be used is Kolmogorov Smirnov test, [2]. For both samples, the value of critical thinking significance of $\mathrm{P}=0.000,<0.05$ to $\mathrm{p}<\alpha$. Thus the samples come from the population distribution is not normal. Because the data distribution is not normal then used the Mann-Whitney test.

We can see that the mean value for the experimental group 76,83 with a standard deviation of 4.930 . As for the control group, the mean is 71, 57 with a standard deviation of 5, 213. From the Mann-Whitney test, the results of statistical p-value = $0.753>0.05$ means the alpha $5 \%$, therefore the test results are not statistically significant. Thus we can accept the null hypothesis that there was no difference in average critical thinking skills between the experimental group and the control group.

After providing treatment through the medium of video during 4 meetings, we can see the difference in value between the experimental group and the control group. To think critically experimental group and the control group had a similar performance. It can be seen from the mean of the experimental group 71,57 and the control group 76.83. For the experimental group using video media utilization and control groups using powerpoint media. Although the media used are different, but the critical thinking skills of both samples are almost the same.

The process of teaching and learning using educational media in schools should be continued, so as to create a quality learning process. Principles of good learning are learning that is able to develop the concept of these materials into the clear and evident. The point is, that the learning process can make a difference in children from not knowing to knowing, and 
understanding of a general nature to be the understanding of the details. Delivery of content will become more apparent when using tools such as instructional media. The media are needed to help students absorb the material well. Teachers should be good at choosing the right media in the delivery of the material so that the media can increase students' interest in learning that will encourage students to be more critical in achieving maximum learning results.

Learning activities should be equipped with sufficient means. The learning process will not achieve maximum results without the media. Number of textbooks by the number of students has to be balanced so that the amount of information and knowledge level of students increased. In addition, the learning process sociology class $\mathrm{X}$ students should be held in the morning, because the morning is the perfect time to learn. Unfortunately, this study had a very limited time, so students are less than the maximum in exploring the media used.

The use of video in the learning process has the goal of keeping the material presentations to be effective and attractive. Through video, students can take advantage of its sensory organs optimally. The more sensing devices used by the students, then the material which is learned will be more easily accepted and remembered.

Teaching and learning process, often faced with the abstract material and outside the experience of students, so that the material is difficult to be taught and understood. Ref. [4] states that "In order to avoid the limitations of thinking, the child needs to be given concrete reality so as to examine the issue. Video presentation, or better known as the "multimedia" is expected to make the visualization more attractive. The more concrete experiences are, the better learning process will be.

Pre-test data obtained by providing an early test to the student before getting material on deviant behavior. The pretest is given in the experimental group and the control group. The goal is to determine the ability of students in the beginning, regardless of learning with models used to determine the readiness of both groups before receiving the new material. Tests were given in five questions in narrative form. The lowest scores obtained by students in pre-test was 42 and the highest was 80 . After being given the treatment with the use of the video media, the lowest post-test score was 65 and the highest was 90. From the provision of pre-test, obtained an average score of students from experimental group was 60,91 while the average value of the post-test experimental group was 77,74 .

Based on the statistical account data, the pre-test experimental group were as follows: (using the 35 students in the sample) values mean $=60.91$, standard deviation $=9.739$ and standard error of the mean $=1.646$. In the post-test value of the experimental class: mean $=77.74$ value standard deviation $=5.198$ and standard error of the mean $=0.879$. From pre-test to post-test an increase in the mean value becomes 16.83 .

Normality test for learning achievement using Kolmogorov Smirnov test, because the sample size in this study is quite large, which is 71 students. According to the table IV learning outcomes for both samples significance value $\mathrm{p}=0.006<0.05$ to $\mathrm{p}<\alpha$. Thus, the samples come from the abnormal population distribution so that $\mathrm{p}<\alpha$. Because the data distribution was abnormal, we used the Mann-Whitney test.

We can see that the mean value for the experimental group was 77.74 with a standard deviation of 5.198. As for the control group the mean value of 70.71 with a standard deviation of 6.032. From the Mann-Whitney test, the results of statistical p-value were $0.00<0.05$ significant at alpha $5 \%$, therefore the test results were statistically significant. Thus, we can accept the alternative hypothesis in which there is an average difference of learning outcomes (post-test) between the experimental group and the control group.

According to [5], the purpose of critical thinking is to achieve a deep understanding. Understanding that makes students understand an event, motivated to find answers and reach an understanding, students examine their own thought processes. Students evaluate the implicit idea of what they hear and read. They feel their own thought processes when writing. Questions like: why, what, and explain - requires students to think and do not give a simple explanation.

According [6] in an organized critical thinking about our thinking process, and thought processes of others will equip students for the information they hear, read, the experience they had and the decisions they make every day. Through critical thinking, students can analyze their own thinking to ensure that they answer correctly and summarize what they have learned.

According to the table IV in the experimental group with a sample of 35 students, the results of the highest pre-test score (maximum) was 80 , the lowest score (minimum) was 40 , and a mean value was 60,91 . Pre-test scores between 40-80 included in the criteria of "less", "sufficient" and "good". While the posttest with the highest scores (maximum) was 90, the lowest score (minimum) 65, mean 77,74. For the post-test scores ranged from 40-80 including the criteria for "enough" and "very good".

The results of the variable Y1 (critical thinking) with Y2 (learning outcomes) obtained 0.500 means that there is a real relationship. According to the table, 24 can be seen that for the experimental group with a sample of 35 students, with a value of $p=>0.002$. This means that the relationship of critical thinking skills to the learning outcomes showed a positive relationship, then $\mathrm{Ha}$ accepted and $\mathrm{Ho}$ rejected mean it is significant. Evidently, think critically affect the study results. The coefficient of determination (R-square) of 0.500 means the positive effect on the real learning outcomes. The magnitude of the correlation numbers between 0.41 to 0.60 means that the correlation between skills, critical thinking and learning outcomes "mediocrity" [3].

The coefficient of determination (R2) of 0.250 can be interpreted: the relationship of critical thinking skills to the learning outcomes by $25 \%$ and the remaining $75 \%$ is influenced by factors that are not investigated. Simple linear regression equation $\mathrm{Y}=41.235$ (a constant value) +0.466 (critical thinking) $\mathrm{X}$. This means, if there are no student learning outcomes or equal to zero- then score the students' critical thinking becomes 41.235. And if the result of learning 
to ride for the unit, then the critical thinking skills about to rise $4.6 \%$.

\section{CONCLUSION}

Based on the results of the data analysis and discussion in this study can be summarized as follows:

1. There is no influence in the use of video learning media to the critical thinking skills of class $\mathrm{X}$ in the subject sociology at SMAN 1 Banyuasin II by using the Mann Whitney test. According to the table II Mann-Whitney test, we can see the output "test Statistic" Asymp value. Sig. (2-tailed) was $0.753>0.05$. Therefore, the test results are not statistically significant, so we can accept the null hypothesis;

2. There is the influence of media use video learning the results of class $X$ on the lessons learned in sociology at SMAN 1 Banyuasin II, Asymp value. Sig. (2-tailed) was $0.00<0.05$. Therefore, the test results are statistically significant. Thus we can accept the alternative hypothesis;

3. There is a positive relationship between critical thinking skills and student learning outcomes in the sociology lesson with the Sig. (2-tailed)> 0.002 greater than 0 , this means that the null hypothesis is rejected and the alternative hypothesis is accepted.

\section{SUGGESTIONS}

Based on the conclusion, it can be submitted suggestions as follows:

\section{A. For The Headmaster}

- Motivate the teachers to improve a creative, innovative and fun instructional media learning
- Facilitate and instructed the teachers to be able to use video media as an alternative to improve critical thinking skills and learning of students' outcomes;

- Striving for the completeness of media equipment to facilitate the learning process.

\section{B. For Teachers}

In order to use video media in all classes. Because based on research, video can improve critical thinking skills and learning outcomes. It is also intended to enable the trial implementation of equal opportunities in the video media in the classroom

\section{For The Next Writer/Researcher}

The results of this study can be considered for research in the future to develop and expand the scope of learning media of sociology.

\section{REFERENCES}

[1] Sugiyono. (2006) . Metode Penelitian Kuantitatif Kualitatif dan R\&D. Bandung : Alfabeta.

[2] Santoso, Singgih. (2012). Aplikasi SPSS pada Statistik Parametrik. Jakarta: Elex Media.

[3] Arsyad, Azhar. (2009) . Media Pembelajaran. Jakarta : Raja Grafindo Persada.

[4] Hamalik, Oemar. (2006) . Proses Belajar Mengajar. Bandung : Bumi Aksara.

[5] Chaffe,J. (1994) . Thinking Critically. Boston: Houghton Mifflin.

[6] Margono. (2005). Metodologi Penelitian Pendidikan. Jakarta : Rineka Cipta. 